\title{
Legal biography at the British Library: a particular perspective on resources
}

\section{Jon Sims}

\section{Abstract}

Rich collections of private archives, antiquarian manuscript collections and published resources make the British Library an obvious choice for biographical research. While these collections include material relating to high ranking legal officials, legislators, renowned legal scholars and their correspondents the article moves beyond this view of legal biographical source materials. Presenting examples of resources from across the Library's diverse collections through a particular perspective on information needs and sources in broadly socio-legal research, a framework for conceptualising the Library's resource is offered together with signposts to discovery aids as contributions to the theme of methods in legal biographical research. In doing so, various notions of the nature of legal biographical research, its subjects and its source information are considered.

\section{Biography}

Jon Sims has worked at the British Library for almost ten years. First as social science reference specialist for law, and currently as curator for law and socio-legal studies. Starting his career at Westminster Reference Library he has developed a particular interest in understanding the legal information needs of diverse audiences.

\section{Article}

Quite apart from existing legal biographies, biographical reference works, newspapers and other formally published materials, a rich body of primary and archival sources is available for legal biographical research at the British Library. Distributed through diverse collections built around holdings of numerous heritage institutions, both integrated and more discrete discovery techniques can be brought to bear on the research process.

A cursory glance at the Oxford Dictionary of National Biography (online) reveals that material pertaining to twelve Lord Chancellors from Thomas More to Quintin McGarel Hogg, and an equal number of Home Secretaries from Robert Peel to James Callaghan are located in the British Library's manuscript and archival collections. Manuscripts and archival sound recordings for numerous jurists and law teachers from William Blackstone to Brenda Hale can also be identified with little effort. ${ }^{1}$ However, legal elites aside, the collections also potentially serve biographical

\footnotetext{
${ }^{1}$ Manuscript and archival material including sound recordings were identified in widely varying quantities for jurists and law teachers, including other Vinerian chairs. Individuals identified in addition to Blackstone and Hale include Robert Chambers, Bentham, Thomas
} 
approaches to investigation of the law in action at a more quotidian level from the perspectives of both lawyers and lay people.

Photographic portraits, judges' notebooks and more formal public records, records of private and institutional legal business, private correspondence and recordings of oral history, current affairs and news interviews are among some of the sources which potentially contribute to biographical research on law. Leaving material traces of legal business and intimate accounts of first hand experiences of law in action, they offer perspectives of well-known and unsung persons with which to observe the daily operation of law or evaluate official, judicial or academic work.

Speaking to the methods theme of the legal biographies training day and a brief to provide a librarian's perspective this article presents resources from a situated, operational view point: collection mapping with a prioritisation of socio-legal research. While signposting discovery aids, the article also offers a particular view of the Library's resource. This view will hopefully prove useful for researchers seeking to conceptualise the resource for research purposes. It also raises also some questions about the natures of legal information need and legal biography.

\section{A lens on the British Library and the identification of legal biographical sources}

Pursuant to Library policy, collection mapping has prioritised socio-legal and related, innovative research that looks to sources beyond those of the Langdellian model of the law library composed predominantly of law reports, legislation and legal doctrinal commentary. ${ }^{2}$ Three conceptual elements used in the mapping template, describing socio-legal information need, legal records and the structure and provenance of British Library collections, provide a structured way of looking at the resource, and have directly influenced the perspective on what resources might be recognised as offering potential value to legal biographical research.

Socio-Legal Information Need

Erskine, Patrick Devlin, Rupert Cross, Andrew Amos, HLA Hart, JR Kenyon, William Jones, Henry Maine, William Alexander Robson, AV Dicey, Frederick Pollock. While the only women law teachers found were Brenda Hale and Vera Baird, both better known for other roles, neither of these lists represent the product of exhaustive searching.

${ }^{2}$ Collection mapping refers to a process used to survey the Library's diverse resources with a view to identifying areas of content strengths for legal research. The process uses an analytical framework or template that includes established schemes of legal information resource, an evolving construction of information need, and awareness of availability of content through other channels. 
Loosely based on an analytical framework of information need outlined by Nicholas, ${ }^{3}$ one that emphasises the purpose or function of information seeking, and the recognition of utility by the seeker as well as subject focus and other criteria, an understanding of socio-legal information need has been constructed from characteristics of socio-legal and interdisciplinary research observed in the literature and from conversations with socio-legal academics. ${ }^{4}$

While making no claims about the generalisability of the sample of literature and conversations, and therefore risking an oversimplification and misrepresentation of the research agenda, this process has suggested that general socio-legal information need might be constructed as a need for sources that would be recognised by the researcher as usefully informing the exploration of

- operational realities, social effects and social impacts (direct and indirect, intended and unintended) of law in action, where ever that action is found, in social settings not limited to appeal courts, including out of court contexts and lay people's encounters with law

- tensions between varied perspectives and discourse about law including dissonance between empirical accounts of the law and entrenched accounts of legal doctrine and the rhetoric of rights and justice, critical perspectives with regard to gender, sexuality, race, class, development, and the construction of meaning with regard to law, conceptions of legal pluralism and diverse systems of normative social ordering, popular and other narrations of law, including non-verbal media as well as textual discourses.

An interpretation of "legal biographical material" from this perspective has suggested that utility might be recognised in, for example, information sources that are able to speak of the life of any particular individual, not just those whose central or influential role in law might be regarded as indicating a life story worthy of research, providing that the material simultaneously informed understanding of, for example, the daily operation of law, its social effects or impacts.

\footnotetext{
${ }^{3}$ Nicholas, D Assessing information needs: tools and techniques for the information age. Aslib, London (2000). This framework draws on the work of M.B. Line.

${ }^{4}$ Examples of the literature include Hutter and Lloyd-Bostock in Hawkins (1997) The Human Face of Law: Essays in favour of Donald Harris (Clarendon1997); D. McBarnet, 'Conclusion and Implications', Conviction (Macmillan, 1981), pp. 154-68. Hollander, D.A. (2007) Interdisciplinary legal scholarship: what can we learn from Princeton's long standing tradition? In Law Library Journal 99(4) 771- 792. See also Twining, Rickman \& Knafla in Twining and Varnden Quick (Eds) in Legal records in the commonwealth (Dartmouth Publishing, 1994); while numerous other characteristic purposes, sites and subjects of study could be mentioned noted areas of interest include law and gender and legal profession.
} 
Legal records

Focusing on library and archival investigation of law in action, Twining's and Knafla's perspectives on the nature of legal records, inform the template through which British Library collections have been surveyed to identify sources whose utility a socio-legal researcher might recognise. ${ }^{5}$ Taking pains to look beyond a typically narrow view of legal records to one that attempts to frame the "potential significance of different kinds of legal records for different classes of users" Twining's (p23) tests recognise the records of varied institutions, the private papers of lawyers, and other classes of legal documents.

Developed with reference to Karl Llewellyn's law jobs theory, Twining's provenance test accommodates a variety of public sector, parastatal and private sector institutions specialised to law. For our purposes it is worth drawing attention to his inclusion of law firms, commercial law publishers, law schools, and legal departments of corporations, as well as the more obvious cogs in the machinery of legal justice. In addition to legislatively prescribed classes of record, Twining's special categories test also recognises classes of legal documents such as simply "contracts".

Together with Knafla's reminder of the theory that "a record is not just a document but any remains (text) of society", ${ }^{6}$ these perspectives furnish the mapping template with a broad yet nuanced understanding of legal records. Providing traces of law in action, these records can be seen as echoes of the lives in which that action was embodied and interpreted: lives that gave effect to law, or on which the law impacted.

\section{Matryoshka}

When seeking to understand how such records and sources that might be recognised as meeting socio-legal information need form part of the British Library

\footnotetext{
${ }^{5}$ Twining's provenance, legislative and special categories tests for the recognition of legal records are set out in Legal records in the commonwealth: a theoretical perspective in Twining and Varnden Quick (eds) Legal records in the commonwealth (Dartmouth Publishing, 1994), p.19 ff. Knafla's "The perspective of the legal historian: legal and sociolegal historical research" is also found in the same work.

${ }^{6}$ Knafla, L The perspective of the legal historian: legal and socio-legal historical research in Twining and Varnden Quick (eds)(1994)(above citation) (p230)
} 
collections, the Russian matryoshka doll serves at varied levels as a metaphor for the many, nested, collections within collections. ${ }^{7}$

At a general level Matryoshka reminds us of provenance, of the collections of heritage institutions at the core of the British Library's developing resource. Examples include the India Office Records, the British Museum's Department of Manuscripts, and the National Sound Archive. However she also works at a more granular level reminding us that within these collections are any number of discrete sets of records: private archives accumulated during their owners' lives, and collections of manuscripts or recordings assembled purposefully and selectively by antiquarians or researchers prior to accommodation at the British Library.

She also reminds us that, notwithstanding the power of increasingly integrated discovery tools, discrete catalogues, indexes, guides, curatorial and accumulated institutional expertise, reading rooms and other access arrangements often reflect the distinct heritage collections and formats. ${ }^{8}$ Furthermore she reminds us of the nested structure of file arrangements and catalogue records of particular archival collections. However, at the limits of Matryoshka's usefulness as a metaphor for the structure and provenance of collections, horizontal relationships between discrete archives within the British Library nest, rendered in the form of catalogue metadata and hyperlinks to associated records, indicate social connectivity, potentially uncharted by existing biography or academic legal research.

\section{Archives and Manuscripts}

Papers of numerous judges, barristers and various other legal officials are found in the Library's collections of private archives, and other manuscripts collections, as

\footnotetext{
${ }^{7}$ The general concept can be extended successfully beyond its application to the Library's printed collections by. Mandelbrote, G and Taylor, B (2009) Libraries within the library: the origins of the British Library's printed collections on the British Library. For an introduction to the Library's various collections see for example About Us http://www.bl.uk/aboutus/index.html, accessed 6/12/13] and Sims, J Librarianship in the $21^{\text {st }}$ Century: a British Library perspective in Legal Information Management, 8 (2008) pp.8491.

${ }^{8}$ Resources such as the National Register of Archives http://www.nationalarchives.gov.uk/nra/default.asp search across the collections of multiple extant repositories including those held by the British Library. EXPLORE http://explore.bl.uk integrates discovery of various British Library collections including printed material, varied digital collections, maps, sound, theses, and others. SOCAM (Search our collections: archives and manuscripts) http://searcharchives.bl.uk integrates discovery of various discrete heritage and developing British Library collections. For further details of British Library catalogues and collection specific guides see the Annex at the end of this article.
} 
well as in the public records of the India Office Archive. Examples of these are provided below.

Moreover, cursory searches have identified large numbers of catalogue records containing records of legal transactions and documents. While these search results signpost numerous instances of categories of legal record recognised by Twining, such as contracts, many will be situated in archival contexts which offer potential for biographically contextualised examination of legal transactions.

Vertical and horizontal relationships

While official records and work related correspondence can be found in archives of public and private institutions, they are also secreted in private archives and antiquarian collections. Private papers, diaries, correspondence, and photographs reflecting the lives and legal work of legal officials and their correspondents may all be found among hierarchically nested private archives. These can be situated in structured series and sub series within discrete, individually named collections including those of for example Gerald Gardiner and George Cave, ${ }^{9}$ as well as in very large multi-generational archives amassed at the country houses of families feeding the bar, the judiciary and positions of elite public legal office.

Crucially however, at a more granular level, material authored by one individual is often dissipated throughout several discrete archives or collections. This can take the form of variously originating private correspondence accreting to/in the archive of the recipient, as is the case with Cornelia Sorabji and Richard Haldane. ${ }^{10}$ Diversely the papers of a single individual have also been consciously selected by antiquarians, and can be found dispersed through multiple collections at the British Library and elsewhere. Examples here include papers of Thomas More (1478-1535) and Francis Bacon (1561-1626). ${ }^{11}$

\footnotetext{
${ }^{9}$ For example the correspondence and papers of George Cave (Add MS 62455-62516 together with Add Ch 76035-76062) including two volumes of formal photographs made in connection with official duties, provide potential insights into his time as Home Secretary (1916-1919), and Lord Chancellor (1922-1924, 24 - 28?). The Gerald Gardiner Papers (Add MS 56455 A-56463 B) predominantly concern the abolition of capital punishment.

${ }^{10}$ For example correspondence with Richard Haldane Lord Chancellor $(1912$ - 1915, 1924) turns up in the papers of Alfred C.W. Harmsworth, Viscount Northcliffe, newspaper and publishing magnate (Northcliffe Papers and Diaries (62153-62397) and in The journal of Sir A W FitzRoy, Clerk of the Privy Council, (Add MS 48371-48380) 1898-1923. Cornelia Sorabji's diaries and private papers as well as work related reports and correspondence are found in Mss Eur F165, her name is also mentioned in the catalogue records of several other archival / manuscript collections at the British Library.

${ }^{11}$ ODNB recognises sources for More among the British Library's Arundel, Cotton, Harley, Royal and Sloane collections, and for Bacon in Additional Manuscripts, Sloane and Lansdowne collections. Papers are also identified by ODNB as being located in various
} 
Family Archives

The Hardwicke papers provide a good example of the large, multigenerational family archive. Here, the papers or two Lord Chancellors are found among a nested structure of series and sub series which, in the first instance, distinguish categories of paper rather than individual persons. ${ }^{12}$ Likewise, the working and private lives of three generations of judges, are archived in similarly structured series and sub series: the Coleridge Family Papers. ${ }^{13}$

The Coleridge papers, the subject of a paper by British Library curator Arnold Hunt, ${ }^{14}$ provide intimate biographical accounts of law in action over the course of almost a century, of work on the assize circuit, on the Kings/Queens Bench and in the Central Criminal Court, of work as Attorney General, Lord Chief Justice, and Privy Councillor (Judicial Committee). Hunt examines how certain material, specifically the bench books, letters and diaries of Sir John Taylor Coleridge $(1790$ - 1876) offer a perspective which challenges both a dominant account of the Victorian judiciary, and our view of the criminal trial obtained from the Old Bailey Proceedings.

Insight is provided on practice at the Old Bailey in general, "a very irksome part of one's duty", sometimes providing a sense of the "tedious" pace and voluminous list, but also offering intimate and particular detail. While bench notes align well with the reported cases, Coleridge's notes regarding sexual offence cases, Hunt reveals, contrast starkly with an absence of coverage in the Proceedings available on Old Bailey Online. ${ }^{15}$ Personal reflections in diary entries and letters home, on trial action in capital cases, on the psychological impacts of sentencing on both litigants and judge, and the social impact with regard to deterrence, on the thought process involved in judicial decision making and occasionally on colleagues, offer rich source material for a biographical approach to the idiosyncrasies of judging, and historical research on the law in action.

Oxford/Bodleian collections, and among State Papers: Henry VIII. In addition to access at the National Archives, calendared, digitised, and in some circumstances micro filmed sets of State Papers can also be accessed at the British Library. See State Papers Online.

${ }^{12}$ Hardwicke papers (MS 35349-36278, 45030-45047), covering the first four Earls of Hardwicke and other members of Yorke families. The series Correspondence includes sub series for Family, Political and General, while the Papers series is subdivided to include subseries including Legal papers. The archive also includes papers relating to other legal offices which the family members held.

${ }^{13}$ Coleridge Family Papers, (MS 85495-86488).

${ }^{14}$ The paper, "Inside the mind of a Victorian Judge: the Coleridge family archive" was presented at The Metropolis on Trial Conference in 2008. Publication is anticipated.

${ }^{15}$ Old Bailey Online http://www.oldbaileyonline.org 
Hunt demonstrates how the sources situate a view on classes of crime, victim and offender, on discretion in judicial decision making, ${ }^{16}$ reliability of evidence, and the judiciary, in very particular experiences. Drawing from what is described as an unusually self-aware, prolific and articulate family archive these sources appear to offer an opportunity to examine the structured cultural context in which these traces of individual, idiosyncratic judicial psychology are situated, but also an opportunity to critique extant scholarship on Coleridge and the Victorian judiciary.

Institutional Archives

Three institutional archives in the British Library collection provide further evidence of legal records that map to Twining's schema and suggest potential utility to the study of law in action through the traces of working lives in law jobs. These archives are the nineteenth and twentieth century correspondence and papers of Macmillan and Company publishers, the Correspondence and papers of the Incorporated Society of Authors, Playwrights and Composers (1879-1968) and the Archive of the Constitution Unit (1995-1997). ${ }^{17}$

From correspondence with Legal historians and jurists in the Macmillan archive we learn something of A.V. Dicey's daily activity and developing thought process that might be brought to bear in a review of his work or an investigation of scholarly communications or the propagation of ideas in general. Letters from Dicey show for example that he requested copies of various of his works to be distributed and put down to his account. These included one copy to be sent to St. Petersburg.

Separately, in July 1913 he wrote to Macmillan stating that he was "getting a good general idea as to the progress of collectivism" and its influence on French legislation. ${ }^{18}$

While the Society of Authors archive (Creation Date: 1879-1968) spans the signing of the Berne Convention in September 1886, and changes in domestic UK legislation, and includes files relating to copyright in other countries, it also includes treatments of copyright law and practice in correspondence with official bodies, authors and others. In the context of copyrights litigated in 1933 we learn of the views expressed by one Mr Medley of Field Roscoe \& Co, Lincolns Inn, to a Society client, on the difficulty in "making judges understand what really happens in regard to cinema production". Sixty one volumes of such correspondence, together with numerous volumes of legal correspondence and papers would appear to provide a

\footnotetext{
${ }^{16}$ Hunt (above reference) refers Coleridge's recorded misgivings about capital sentencing and his thoughts on a socio-geographically contextualised consideration of deterrence and proportionality at a point in time (1835) when capital statutes were reportedly being repealed.

${ }^{17}$ SOCIETY OF AUTHORS ARCHIVE Reference: Add MS 56575-57264; Creation Date: 18791968; THE MACMILLAN ARCHIVE. Add MS 54786-56035 and Add. 61894-61896; Constitution Unit Archive 87373-87451. Archive of the Constitution Unit; 1995-1997.

${ }^{18}$ Within the Macmillan Archive, Add MS 55082-55088 cover Legal historians and jurists. The mention of collectivism is found in f.51 of Add MS.55085.
} 
substantial source for reconstructing at least a partial view of law in action from the perspective of Mr Medley. ${ }^{19}$

India

While records of the administration of justice in India to 1947 are found in the public records of India Office archive, private papers relating to the administration and operation of local and colonial justice are also found among collections of private papers. ${ }^{20}$ Leaving traces of the lives and law jobs of varied well known and unsung officials in the administration of justice and the provision of legal advice are for example Public and Judicial Department correspondence, Service Histories and Judicial and legislative Proceedings.

Private papers include for example those of Warren Hastings, (Governor of Bengal, instrumental in the introduction of legal codes) Elijah Impey and Robert Chambers, (both Justices of the Calcutta Supreme Court, the latter succeeding William Blackstone in the Vinerian Chair). Complementing the correspondence of Frederick Pollock found in the Macmillan archive, papers of fellow historical jurist and official of the British administration in India, Henry Maine are found both in the India Office public records and among series of private papers.

Complimenting a biographical approach to the Calcutta High Court, at a more every day, although hardly mundane level, the papers of George Charles Farr, attorney (High Court at Calcutta), and solicitor in England are also found among European Manuscripts collections. Some of his papers are identifiable as relating to particular Privy Council appeals. More exceptionally, the work and private reflections of Cornelia Sorabji, who sat and law exams 27 years before women in Oxford gained the right to receive their degrees in 1919, and worked as adviser to the court of wards before practicing at the high court Calcutta from 1924, are recorded in diaries, correspondence and papers. ${ }^{21}$

\footnotetext{
${ }^{19}$ Within the Society of Authors Archive series C. LEGAL FILES (Add MS 56899-57001) includes thirteen sub series. Just one of these is the 61 volumes of "Correspondence with Field Roscoe \& Co., chiefly with C. D. Medley; Creation Date: 1908-1954. The particular correspondence is identified as ff 7-8 of 250 folio bound in Vol. CCCLXXXV Add MS 56959 covering $1933-37$ and 1954
}

${ }^{20}$ Histories of service are found in IOR/V/13; both Judicial and Legislative Proceedings are nested with the series IOR/P, Public and Judicial Department correspondence in IOR/L/PJ/6, 7 Private papers are found in the European Manuscripts collection MssEur but may also be located in other manuscript collections at eth BL with use of the integrated archives and manuscripts catalogue SOCAM. (See earlier note)

\footnotetext{
${ }^{21}$ Source: Uparna Gooptu, 'Sorabji, Cornelia (1866-1954)', in Oxford Dictionary of National Biography, OUP 2004; online edn, Jan 2011 [http://www.oxforddnb.com/view/article/36195, accessed 9 Dec 2013] Sorabji is the subject of several biographical publications found in the Library's printed collections. Her papers are found at Mss Eur F165, while her name is also mentioned in the catalogue records of several other archival / manuscript collections at the British Library. See also
} 


\section{Sound and Vision}

While portraits are occasionally found among the archival collections of private papers (for example those of George $\mathrm{Cave}^{22}$ ) and may also be located across library collections, ${ }^{23}$ recorded sound and moving image collections deserve particular attention. Numerous archival recordings, including oral histories and radio interviews, as well as broadcast televisual news and BBC archival resources offer potential insight on the lives of lawyers and justice officials, as well as the legal experiences of lay people.

Archival sound recordings include interviews with and other coverage of for example activists for gender equality, legislators, barristers, solicitors, a police officer, a defendant at trial, judges, criminals, a prison inspector, and a penal reformer. ${ }^{24}$ While broadcast televisual news and BBC archival recordings require further investigation and can be explored via services indicated in the annex below, oral history has received some focus with regard to life course accounts of the law. ${ }^{25}$

Most obviously the Legal Lives oral history collection presents interviews with at least nine legal professionals in elite positions. Complementing potential perspective on the rhetoric of the separation of powers and on institutional reform that might be gleaned from papers of Constitution Unit (see above), one of the many subjects discussed in Legal Lives recordings with Brenda Hale made between 2008 and 2010, is the new Supreme Court. ${ }^{26}$

Distinctly from the Legal Lives collection, Jean Graham Hill (1917 - 2005), arbitrator and lawyer, is the subject of an interview within the Fawcett collection's theme of pioneering women in male dominated professions, while interviews with legal officials participating in trials of far reaching political significance include Joel Joffe,

'Cornelia Calling' - A Voyage of Discovery in the British Library -

http://britishlibrary.typepad.co.uk/untoldlives/2013/12/cornelia-calling-a-voyage-ofdiscovery-in-the-british-library.html

${ }^{22}$ See above, note 9.

${ }^{23}$ In addition to the ODNB online, see Annex for details of finding aids for images and portraits.

${ }^{24}$ While more incisive discovery aids may be deployed, brief detail relating to some of these examples may be found via ODNB online.

${ }^{25}$ Details of the Legal Lives and the other law related oral history collections mentioned here are provided, unless otherwise stated, in the following collection guide Oral history: law and the legal system http://www.bl.uk/reshelp/findhelprestype/sound/ohist/ohcoll/ohlaw/law.html ${ }^{26}$ Interviews with Lady Hale conducted by Paula Thomson are part of the National Life Stories Collection: Legal Lives (Reference C736/08) Summaries of the interviews may be read on the Cadensa. See Annex below for link. 
defence lawyer for Mandela at Rivonia, and Hartley Shawcross (prosecutor at Nuremberg). ${ }^{27}$ Biographical perspectives on the law and politics are also present in interviews with John Platts-Mills and other recordings pertaining to politics and government. $^{28}$

Other biographical stand points, less represented in traditional modes of legal research, on the daily operation and impact of law are provided in the The Millennium Memory Bank collection. Perspectives from all walks of life and from geographical locations across the UK, on Crime and Law among other themes are captured from over 6000 people, by this BBC / BL collaboration. Separately, from the perspective of those giving effect to the law at street level, an oral history collection on English Policing constitutes the research data for Barbara Weinberger's 1995 publication. Seeking again everyday perspectives on the operation of law, the focus of a new collaborative oral history programme with the LSE hopes, over the coming years, to shed light on policy shifts in the administration of justice from the accounts of Crown Court clerks.

Other accounts of the law from outside the lawyer's perspective may be found in the newly completed Sisterhood collection. With brief extracts available freely online, this collection provides a rich body of oral histories describing the social environment impacting on and spurring the women's movement from the 1970s and after. The collection includes first-hand accounts of the impact of legislation on women's lives, of activism and the political and cultural contexts in which new anti-discrimination legislation and court judgments were forged. For example while lawyer, politician and Fawcett Commissioner Vera Baird refers to the twenty first century investigation of women as victims, witnesses, defendants, and workers in the criminal justice system, Lesley Abdella talks of an experience of gender discrimination in the workplace prior to the Sex Discrimination Act of 1975, and footballer Sue Lopez talks about the intersection of sporting and legal rules with judicial interpretation of changing social norms through the Sue Bennett case. ${ }^{29}$

\section{Printed material}

\footnotetext{
${ }^{27}$ On Mandela see also Rescuing the Rivonia Trial recordings a Sound and Vision blog posting including clips of the three hour speech from the dock of Accused No.1. [ http://britishlibrary.typepad.co.uk/sound-and-vision/2013/12/rescuing-the-rivonia-trialrecordings.html Accessed 27/12/2013]
}

\footnotetext{
${ }^{28}$ This interview is part of the Labour Lives. Other oral history projects with interviews containing accounts of the law include City Lives http://www.bl.uk/reshelp/findhelprestype/sound/ohist/ohnls/ohcit/citylives.html and collections pertaining to parliament, government and politics http://www.bl.uk/reshelp/findhelprestype/sound/ohist/ohcoll/ohpol/politics.html ${ }^{29}$ Sisterhood and After: An Oral History of the Women's Liberation Movement can be explored at a surface level through thematic and biographical pages freely available at http://www.bl.uk/learning/histcitizen/sisterhood/index.html [Accessed 27/12/2013]
} 


\section{Privy Council cases}

Before belatedly coming to the fact that the British Library actually contains some books, another printed source that speaks of the law in action through the biographies of the litigants constructed as part of legal process, deserves a particular mention: records of proceedings re-produced from courts across the British colonial world for appeal hearings of the Judicial Committee of the Privy Council. ${ }^{30}$

While uninformative about the impact of law on litigants' stories post judgment, these sources place litigants' lives, their legal problems and encounters with legal institutions, in frequently protracted proceedings, centre stage. While appeal cases are exceptional by definition, these legally constructed life stories never the less offer loud echoes of the law in action, providing opportunities to reappraise abstract appeal judgments, some of which remain authoritative, in light of tangible exhibits, process and dialogue of the lower courts. ${ }^{31}$ As such they allow us to hear frequently hidden voices and perspectives: of individuals, those of an international and openly constructed sample of litigants, but also of institutions, those of the lower courts across the British colonial world. ${ }^{32}$

\section{Published biographies}

The dimensions of the Library's collection of published legal biographies are hard to assess. Such a collection is only notionally discrete. However certain characteristics can be described.

\footnotetext{
${ }^{30}$ While the notion of law reports as a source "life stories" is indebted to Twining (Hamlyn law Lectures, forty sixth series. Blackstone's Tower: the English Law School (Published under the auspices of the Hamlyn Trust, London, Stevens \& Sons/Sweet and Maxwell, 1994) p.103, the idea of legal proceedings that led to Privy Council appeal contributing to the construction of identity is indebted to Nandini Charterjee.

${ }^{31}$ Notions posited here of the type of utility these sources potentially offer for socio-legal study are indebted to Matthew Weait's "Criminal law: thinking about criminal law from a trial perspective" in Integrating socio-legal studies into the law curriculum. PalMac, Hunter, C (ed) 2012

32 Details of the collection Appeal Cases Heard Before the Judicial Committee of the Privy Council (British Library Shelf mark PP1316), can be found on the British Library website at http://www.bl.uk/reshelp/findhelpsubject/busmanlaw/legalstudies/privycouncil/jcpc.html For insight on particular life stories as narrated by Privy Council proceedings please see the following blog posts reproduced with permission from a report by Alex Giles: Stories from the Empire: Privy Council Cases 1917-1920

http://britishlibrary.typepad.co.uk/socialscience/2013/12/stories-from-the-empire-privycouncil-cases-1917-1920.html\#sthash.WJOXopcy.dpuf continued at http://britishlibrary.typepad.co.uk/socialscience/2013/12/stories-from-the-empire-privycouncil-cases-1917-1920-contd.html\#sthash.nbav9CCi.dpuf and Women of the Empire: $a$ Privy Council case http://britishlibrary.typepad.co.uk/untoldlives/2013/12/women-of-theempire-a-privy-council-case.html
} 
Pursuant to the legal deposit acquisition stream, and subject to the effective satisfaction of this statutory requirement, ${ }^{33}$ legal deposit libraries' archives of printed books contain, by default, varied modes of legal biography published and distributed in the UK and Ireland. Beside a wider, empirically or biographically informed literature on judging and lawyering or the legal professions more generally, this notional collection includes singular and collected works of academic legal biography. Its scope also extends to works of autobiographical bonhomie in the vein of maxims and malts: forty years at the equity bar, ${ }^{34}$ and self-published works ${ }^{35}$ offering all that these genre may reveal about legal culture and everyday legal practice. However purchased and other acquisition streams also include biographical treatments of lawyers in varied fields of practice, published in and focusing on countries with a range of single and mixed legal systems, as well as works focusing on international lawyers.

Beyond the UK the geographical range of publication among a selection of recently published legal biographies includes works based in common law, mixed common law systems and international legal orders as well as works from continental Europe. A work in Polish concentrates on lawyers at the University of Wroclaw. ${ }^{36}$ A 2013 work published in Prague gives biographical accounts of Czech political prisoners, lawyers and the Sachsenhausen concentration camp. ${ }^{37}$ From South Africa, Bobb Hepple's memoir of Rivonia and detention without trial work supplements sources at the British Library and beyond. ${ }^{38}$ In Representing the Race Kenneth Mack offers biographical accounts of cause lawyering, the creation of the civil rights lawyer and

\footnotetext{
${ }^{33}$ A statutory duty on UK and Irish publishers and distributors to deposit one copy of printed works with each legal deposit library has been statutorily provided since 1662 . This situation has recently been evolving with regard to non-print works. For more information see http://www.bl.uk/aboutus/legaldeposit/

${ }^{34}$ This is an invented title. Any similarity to specific works or individuals is entirely coincidental.

${ }^{35}$ An example is the autobiography of Roger Terrell An unusual brief: the life and times of a high street lawyer (Peterborough: Fastprint Pub., 2012) (Legal Deposit. British Library Shelf Mark YK.2012.a.30507) from an advertisement in the Law Society Gazette (Gazette. 18-OCT2012, p.36) [http://www.lawgazette.co.uk/roger-terrell/3630.bio accessed 27/12/2013] appears to offer insight into everyday high street practice as well as more exceptional work. ${ }^{36}$ Published in series as Acta Universitatis Wratislaviensis; part 3423 (Exchange agreement. British Library shelf mark Ac.868.c/3(3423)),

${ }^{37}$ Kuneš Sonntag: životní příběh z dvacátého století. Jindřich Fiala, interviewer. Praha: Nakladatelství P3K, 2013. (Purchased. British Library shelf mark YF.2013.a.19650) ${ }^{38}$ Young man with a red tie: a memoir of Mandela and the failed revolution, 1960-1963 / Bob Hepple. Auckland Park, South Africa: Jacana Media, 2013. (Purchased. British Library shelf mark YP.2013.a.6025.) Recordings of Mandela and Joffe are mentioned above. Interviews with Hepple form part of the Eminent Scholars Archive at Cambridge http://www.squire.law.cam.ac.uk/eminent scholars/professor sir bob hepple.php.
} 
conflicted identity of African American lawyers. ${ }^{39}$ While a 2011 collection provides interviews with elite, male international lawyers, ${ }^{40}$ a US published collection covers women "at all stages of their law careers" ${ }^{41}$ and works on pioneering women lawyers may also be read in conjunction with sources at the British Library and beyond. ${ }^{42}$

\section{Search and Discovery}

While a range of catalogues and discovery tools that provide useful access points to material for biographical research are listed in an annex below, if not already mentioned in notes, a few hints offer some particular suggestions about the use of specific finding aids.

\section{Explore}

With certain limitations "Explore" can be used to construct virtual, collections of published legal biography in the form of browse-able catalogue search results. ${ }^{43}$ Results of an initial key word search subsequently can be refined using subject, genre and other descriptive metadata. This process enables assembly of browseable collections of records restricted in scope. For example a simple key word search on "lawyers" refined by Genre to Biography produced over 500 hits, the vast majority of which were published after 1996. Further refinements include for example Jewish lawyers or law teachers. However the retrieval system's ability to identify the entire "collection" is only as good as the metadata and semantic stability allow. Subject and genre metadata is not always present in catalogue records. While some works on lawyers that one would reasonably expect to be labelled as biography are not, other bibliographic records are very minimal, consisting of little more than author, title and publication date. Among the subject metadata used in the catalogue records to describe published biographies cited above, the terms "lawyers - personal narratives" and "lawyers - interviews" were also applied.

${ }^{39}$ Representing the race: the creation of the civil rights lawyer. Kenneth Walter Mack. Cambridge, Mass. Harvard University Press, 2012. (Legal Deposit. British Library shelf mark YC.2012.a.9947)

${ }^{40}$ Five masters of international law: conversations with R-J Dupuy, E. Jiménez de Aréchaga, R. Jennings, L. Henkin and O. Schachter / Antonio Cassese. Oxford: Hart Publishing, 2011. (Legal Deposit. British Library shelf mark YK.2012.a.18080).

${ }^{41}$ Reaching the bar: stories from women at all stages of their law careers" / edited by Robin Sax. New York: Kaplan, c2009 . (Legal Deposit. British Library shelf mark YK.2010.a.5620.) ${ }^{42}$ The story of the first woman admitted to the California bar can be explored in Woman lawyer: the trials of Clara Foltz / Barbara Babcock. Stanford, Calif. : Stanford University Press; London: Eurospan [distributor], 2011. (Legal Deposit. British Library Shelf Mark) as well as via Stamford University's Women's Legal History Biography Project at http://wlh.law.stanford.edu/woman-lawyer/ accessed 27/12/2013) Cornelia Sorabji (bachelor of civil law in 1892, called to the bar 1923. Source ODNB online), whose private papers at the British Library are mentioned elsewhere in this article, is the subject of several published biographies.

${ }^{43}$ See note 8? Explore, the British Library's main catalogue covering, among other materials, printed, and increasingly, digitised and born-digital books. 
SOCAM, archival and manuscript collections and distributed discovery

The matryoshka metaphor is recalled particularly in relation to the hierarchical structure of archival and manuscript catalogue records. While person and other searches can be performed with the help of SOCAM, ${ }^{44}$ clicking beneath the individual record on "Detail" offers links ("See contents" or "Is part of..") that facilitate exploration of the nested collection level, series, sub series and fond records that structure the records of larger collections. ${ }^{45}$ In the case of certain private archives, cataloguing is provided to the level of individual folio.

Crucially however, where cataloguing reaches this level of granularity, catalogue functionality also enables horizontal discovery. Recalling the previously mentioned distribution of papers authored by or pertaining to a single individual throughout varied collections, the integrated archives and manuscripts system SOCAM, permits direct linking to records describing items held in parallel collections and files, in which the individual concerned is identified as the subject or author. While this facilitates discovery of distributed papers such as correspondence archived by the recipient for example, in the case of material incidentally accreted and retained in archives rather than consciously developed by antiquarians, it also surfaces social connections, and begs the question of whether diagrammatic renditions of these social networks can be generated and usefully exploited. ${ }^{46}$

While possibilities of linking between sub collection-level descriptions to records beyond SOCAM is beyond the scope of his article, finding aids such as the National Register of Archives or Oxford Dictionary of National Biography Online place sibling British Library collections, such as those previously noted for More and Bacon, within the context of the wider distributed collection. Similar connections to material pertaining to an individual's encounters with the law held in diverse collections, including British Library sources, can also be made through Connected Histories. This interface facilitates the construction of biographical accounts by drawing from diverse digital sources including Old Bailey Online (OBO) and numerous other qualitative data sets, as well as various additional materials at the British Library. The use of Connected Histories to reconstruct geographically grounded life stories

\footnotetext{
${ }^{44}$ See note 8 ?

${ }^{45}$ For example see the SOCAM records for the Coleridge or Cave papers (previously cited). Search refinement options to the left of the screen also offer the ability to select or deselect records relating to series, sub-series, or fond. While the India Office records can also be searched and browsed in this manner, an outline of their structure can be usefully gained from the Library website (http://www.bl.uk/reshelp/findhelpregion/asia/india/indiaofficerecords/indiaofficearrange ment/indiaofficearrangedrecord.html Accessed 27/12/2013)

${ }^{46}$ Hyper-links connecting the catalogue user to occurrences of the person of interest as the author or "Subject of..." a paper or file described in an associated record are visible on the right hand side of catalogue records identifying the individual or institution in question by selecting "Detail".
} 
and encounters with law is demonstrated elsewhere. ${ }^{47}$ However it is worth pointing out that OBO's Associated Records database reveals un-digitised British Library content relating to more than 3000 Old Bailey trials as well as public records that are available through subscription sources in the reading rooms. ${ }^{48}$

\section{Conclusions}

By starting with descriptions of the lens used to survey and map British Library collections and of the purpose of that mapping process this article has sought to share the rationale for a particular view of what might constitute legal biographical sources. In turn these sources offer suggestions of varied views of the nature of legal biographical research.

While private and institutional archives provide resources for an uncomplicated view of legal biography as the life story of a legal figure, they also support views of legal biography as the use of biographical materials to review what is known of an individual's academic or official work, specific judgments, and so on. Similarly they support a view of legal biographical research as the use of such materials to review existing historical accounts of legal professions or to build new accounts of the professions, wider society or events.

Proceedings in Privy Council cases indicate a view of legal biography as life stories constructed and perpetuated by process of litigation and appeal, and, together with the resources demonstrated in the cited accounts of Connected Histories, and British Library resources identified by the Additional Resources database of Old Bailey Online, as the records of that process. Further accounts of litigants' and other lay people's legal encounters also offer a view of legal biography as the exploration of law in action from these external perspectives on law. While oral history in itself produces biographical accounts of law, its outputs are utilised in the exploration of

\footnotetext{
${ }^{47}$ The stories of a C19th convict and C18th constable are recounted, with the help of Connected Histories, by Jane Winters in, respectively, an IHR blog post (7th November 2011) [ http://ihrhistory. blogspot.co.uk/2011/11/bringing-together-old-bailey.html Accessed 27/12/2013] and Past and Future, Autumn 2010, p14

[ http://issuu.com/schoolofadvancedstudy/docs/past-and-future-2010-autumn.pdf Accessed 27/12/2013]

${ }^{48}$ From OBOs own Associated Records database [http://www.oldbaileyonline.org/forms/formAssociatedRecords.jsp Accessed 27/12/2013] the lives of defendants in criminal proceedings can be traced further through to separate accounts in well over 3000 associated records held at the British Library. In addition, citations in the Associated Records database to entries in the calendars of State Papers can be used to go directly to the full text of these public records in State Papers online. Both the printed calendars and the State papers Online are available in the British Library reading rooms.
} 
law in action from the perspectives and life stories of its subjects whether lawyers or lay people.

In the process of exploring the Library's resource in this way a number of examples of material distributed across the diverse collections appear to map to the template's view of socio-legal information need. For example concurrence is found with regard to the study of law in action as experienced by lawyers, their clients and other lay people in copyright practice observed in the Society of Authors archive, or in the thought process and socially effected legal decision making of the Victorian judge as seen in the Coleridge Family Papers, or the social context in which antidiscrimination legislation was engendered seen in the oral histories of Sisterhood and After. Similarly we have seen examples of resonance between the mapping template's view of legal records and British Library resources including public and private institutional archives, private papers of lawyers, and other remains of a socially constituted view of what law is.

While the article's assertion of what might constitute socio-legal information need can be validated only by recognition of utility on the part of the researcher, the adopted approach has sought to offer a way of conceptualising the resource for varied notions of biographical legal research. In doing so, material more and less commonly associated with biographical research has been identified. Whether or not the utility of these materials is recognised by researchers engaged in legal biography remains to be seen.

\section{Annex}

British Library collection guides for biography

- Finding Biographical information (Reader Guide 10) http://www.bl.uk/reshelp/pdfs/ReaderGuide10.pdf

- Biographical Sources on Microfiche http://www.bl.uk/reshelp/findhelprestype/microform/artsandhum/biomicrofiche. html

- Biography: reference sources http://www.bl.uk/reshelp/findhelprestype/refworks/biog/biogref.html

Biographical databases (available in St. Pancras reading Rooms) http://www.bl.uk/eresources/ahsub/elecsuboff1.htm|\#Biography

Resources include

- Dictionary of National Biography (DNB \& Oxford DNB online)

- Biography and genealogy master index (BGMI)

- World biographical information system

Legal Biography reference sources 
- A number of dictionaries of legal biography and other relevant reference materials can be located on the open shelves in the Humanities reading room (lower level). HLR 340s or by searching Explore. (see catalogues below)

- For guides to local history society publications, and other lists and indexes, and genealogical resources please consult Humanities reference services.

\section{Catalogues}

A full list of British Library catalogues including EXPLORE (for printed materials and other formats including certain sound recordings and newspapers), SOCAM (the integrated archives and manuscripts catalogue including India Office Archives but excluding National Sound Archive material), and many other specialist resources can be found via the Catalogues tab on the Library home page. www.bl.uk

\section{Collection Guides}

Guides to collections including guides resource type including named collections of manuscripts such as the Hardwicke papers can be found via the Collections tab on the Library home page. www.bl.uk

India

- Indie Office Finding Aids

http://www.bl.uk/reshelp/findhelpregion/asia/india/indiaofficerecords/indiaoffice hub.html

- Arrangement of the India Office Records, and List of Classes http://www.bl.uk/reshelp/findhelpregion/asia/india/indiaofficerecords/indiaoffice arrangement/indiaofficearrangedrecord.html

Sound and Vision

- CADENSA Sound and Moving Image Catalogue http://cadensa.bl.uk/cgi-bin/webcat

- Help and Guides for Oral History Collections http://www.bl.uk/reshelp/findhelprestype/sound/ohist/oralhistory.html

- Oral History Collections - Law and Legal System http://www.bl.uk/reshelp/findhelprestype/sound/ohist/ohcoll/ohlaw/law.html

- Oral history Bibliography http://www.bl.uk/reshelp/findhelprestype/sound/ohist/ohresources/oralhistoryr esources.pdf

- Reference books for oral history are available in the Humanities reading room (upper level) 
- Sounds Website http://sounds.bl.uk/oral-history

- Sound Collections

http://www.bl.uk/reshelp/findhelprestype/sound/index.html

- Moving Image collections

http://www.bl.uk/reshelp/findhelprestype/movingimage/movingimagecoll/index. $\underline{\mathrm{html}}$

This web page provides details of collections and discovery and delivery resources including the BBC Pilot Service and Broadcast News which can be accessed only in the St. Pancras reading rooms

- Images Online https://imagesonline.bl.uk

- Photograph Catalogues http://www.bl.uk/catalogues/photographs/

- Portraits: reference sources

http://www.bl.uk/reshelp/findhelprestype/refworks/portraits/portraits.html 